\title{
Multi-generational oxidation model to simulate secondary organic aerosol in a 3-D air quality model
}

\author{
S. H. Jathar ${ }^{1,2}$, C. D. Cappa ${ }^{1}$, A. S. Wexler ${ }^{1}$, J. H. Seinfeld ${ }^{3}$, and M. J. Kleeman ${ }^{1}$ \\ ${ }^{1}$ Civil and Environmental Engineering, University of California, Davis CA, USA \\ ${ }^{2}$ Mechanical Engineering, Colorado State University, Fort Collins CO, USA \\ ${ }^{3}$ Chemical Engineering, California Institute of Technology, Pasadena CA, USA \\ Correspondence to: M. J. Kleeman (mjkleeman@ucdavis.edu)
}

Received: 4 February 2015 - Published in Geosci. Model Dev. Discuss.: 20 February 2015

Revised: 22 May 2015 - Accepted: 15 July 2015 - Published: 13 August 2015

\begin{abstract}
Multi-generational gas-phase oxidation of organic vapors can influence the abundance, composition and properties of secondary organic aerosol (SOA). Only recently have SOA models been developed that explicitly represent multigenerational SOA formation. In this work, we integrated the statistical oxidation model (SOM) into SAPRC-11 to simulate the multi-generational oxidation and gas/particle partitioning of SOA in the regional UCD/CIT (University of California, Davis/California Institute of Technology) air quality model. In the SOM, evolution of organic vapors by reaction with the hydroxyl radical is defined by (1) the number of oxygen atoms added per reaction, (2) the decrease in volatility upon addition of an oxygen atom and (3) the probability that a given reaction leads to fragmentation of the organic molecule. These SOM parameter values were fit to laboratory smog chamber data for each precursor/compound class. SOM was installed in the UCD/CIT model, which simulated air quality over 2-week periods in the South Coast Air Basin of California and the eastern United States. For the regions and episodes tested, the two-product SOA model and SOM produce similar SOA concentrations but a modestly different SOA chemical composition. Predictions of the oxygen-tocarbon ratio qualitatively agree with those measured globally using aerosol mass spectrometers. Overall, the implementation of the SOM in a 3-D model provides a comprehensive framework to simulate the atmospheric evolution of organic aerosol.
\end{abstract}

\section{Introduction}

Fine-mode organic particulate matter or organic aerosol (OA) accounts for roughly half of the dry ambient aerosol mass yet it remains one of its least understood constituents (Jimenez et al., 2009). Ambient OA exists as a complex mixture of thousands of compounds with very different physical and chemical properties that arise from a host of sources and reaction pathways (Goldstein and Galbally, 2007). This OA and the organic vapors in equilibrium with it together form a dynamic system in which their mass, chemical composition and environmental properties are constantly evolving as a result of gas-, surface- and particle-phase reactions coupled to condensation and evaporation. The complexity and dynamic behavior have made it difficult to identify and model the dominant pathways that control the atmospheric burden of OA, which limits our ability to quantify its climate- and health-relevant properties.

OA is either directly emitted as primary organic aerosol (POA) or formed in the atmosphere from the oxidation of volatile organic compounds (VOC) as secondary organic aerosol (SOA). Most box (0-D) and large-scale (3-D) models represent SOA production from the gas-phase oxidation of certain VOCs (large alkanes, aromatics, isoprene and terpenes) to yield 2-4 low-volatility products that partition into the particle phase (Odum et al., 1996; Carlton et al., 2010; Lane et al., 2008). Laboratory chamber data provide the basic information on which these SOA formation models are built. It is widely recognized that gas-phase VOC oxidation products (or more generically organic vapors) can undergo multi-generational oxidation, given sufficient time in the at- 
mosphere, which may substantially alter the mass and properties of SOA. For example, chamber studies using surrogate molecules - aldehydes to represent gas-phase oxidation products of alkanes (Chacon-Madrid et al., 2010) and biogenic VOCs (Chacon-Madrid et al., 2013) and phenols to represent those from aromatics (Yee et al., 2013) - have highlighted the potential of VOC oxidation products to undergo multi-generational oxidation to form SOA. In chamber experiments conducted at four different facilities, Donahue et al. (2012b) showed that semi-volatile organic vapors, formed from the ozonolysis of $\alpha$-pinene, subsequently reacted with the hydroxyl radical $(\mathrm{OH})$ to enhance SOA mass concentrations. While it is likely that virtually all oxidation products from SOA precursors subsequently react, what is less clear is the relevance of multi-generational oxidation of different classes of SOA precursors to the concentrations and properties of ambient OA under typical atmospheric conditions.

Laboratory chamber studies, on account of their reaction times and typical oxidant levels, are dominated by products from the first few generations of VOC oxidation; a typical chamber experiment captures from one-half to 1 day of atmospheric oxidation and does not fully replicate the typical atmospheric lifetime of reactive organic compounds. However, since second- and later-generation products are often likely to have lower vapor pressures and thus greater SOA formation potential, SOA formation may be influenced by later-generation products even at short oxidation lifetimes. A few simple schemes have attempted to account for this multi-generational oxidation within air quality models. Most often, multi-generational oxidation has been implemented by allowing for the parameterized surrogate semi-volatile product species to undergo further "ageing" reactions. For example, Robinson et al. (2007) assumed that primary organic vapors (semi-volatile and intermediate volatility organic compounds; SVOCs and IVOCs) sequentially react with $\mathrm{OH}$ to form products that are an order of magnitude lower in volatility than their precursor. Pye and Seinfeld (2010) represented the same pathway through a single-step reaction that reduced the volatility of the vapors by 2 orders of magnitude. Lane et al. (2008) and Baek et al. (2011) modeled ageing of semi-volatile SOA vapors by assuming that each reaction with the $\mathrm{OH}$ radical resulted in progressively lower volatility products. While such schemes have the potential to improve model-measurement comparisons, they have at least three major drawbacks. First, they do not consider the role of fragmentation, which has been shown to be quite important for oxygenated SOA precursors (Chacon-Madrid and Donahue, 2011) and can lead to decreases in SOA concentrations. Second, they assume that the oxidation reactions proceed similarly for products from different classes of SOA precursors, i.e., multi-generational oxidation of alkane, aromatic, or biogenic SOA is the same. Finally, current schemes have not been tested against or constrained by measurements of multigenerational products (or classes of products) under realistic ambient conditions.
Multi-generational VOC oxidation, in theory, can be explicitly modeled using detailed gas-phase chemical mechanisms such as the MCM (Master Chemical Mechanism; Jenkin et al., 2003; Saunders et al., 2003) or GECKO-A (Generator of Explicit Chemistry and Kinetics of Organics in the Atmosphere; Aumont et al., 2005; Camredon et al., 2007) and have been put to use to develop a better understanding of the reaction chemistry leading to SOA formation (Yee et al., 2012; Aumont et al., 2012; Valorso et al., 2011). However, these mechanisms track thousands to millions of chemical species and are computationally impractical for modeling multi-generational oxidation in 3-D models. Recently, there has been the development of two frameworks of intermediate complexity that allow for the treatment of multi-generational oxidation (and other aerosol processes) during SOA formation: the two-dimensional volatility basis set (2D-VBS) that uses vapor pressure and the $\mathrm{O}: \mathrm{C}$ (oxygen to carbon) ratio as the independent variables (Donahue et al., 2011; Donahue et al., 2012a) and the statistical oxidation model (SOM) that uses the number of carbon atoms and oxygen atoms per molecule as independent variables (Cappa and Wilson, 2012). Both have provisions to treat fragmentation of the reactants as a function of their oxygen content and can be parameterized from chamber measurements (Cappa et al., 2013; Zhao et al., 2015). Both frameworks require tracking on the order of hundreds of model species, which is more computationally expensive than models with less detail, but still sufficiently modest to be realistically implemented in 3D models today.

This work describes the first implementation of the SOM model of Cappa and Wilson (2012) in a 3-D air quality model. Details are provided regarding (a) the SOM parameterization using recent low and high $\mathrm{NO}_{x}$ chamber data for six different classes of SOA precursors, (b) the integration of SOM with the gas-phase chemical mechanism SAPRC-11, and (c) the coupling of SOM with the UCD/CIT (University of California, Davis/California Institute of Technology) model to make air quality predictions over 2-week periods in the South Coast Air Basin (SoCAB) of California and the eastern United States (US). General results from the simulations are discussed and briefly compared with results from a current-generation SOA model.

\section{Model description}

\subsection{3-D air quality model}

The UCD/CIT air quality model is a regional chemical transport model (CTM) (Kleeman and Cass, 2001) that has been extensively used for predicting regional aerosol concentrations, including SOA (Chen et al., 2010; Kleeman et al., 2007). The UCD/CIT model simulates the emissions, transport, gas-phase chemistry, aerosol physics and chemistry (dynamic gas/particle partitioning, coagulation, 
thermodynamics and deposition) in the lower troposphere. The UCD/CIT model employs the condensed form of the SAPRC-11 gas-phase chemical mechanism to simulate gasphase chemistry (Carter and Heo, 2013) and ISORROPIA to model inorganic aerosol thermodynamics (Nenes et al., 1998). Aerosols are represented using an eight-bin moving sectional approach to encompass a size range of $10 \mathrm{~nm}-$ $10 \mu \mathrm{m}$.

The model simulated air quality in two domains: (1) the state of California at a grid resolution of $24 \mathrm{~km} \times 24 \mathrm{~km}$ followed by a nested simulation over SoCAB at a grid resolution of $8 \mathrm{~km} \times 8 \mathrm{~km}$ and (2) the eastern half of the US, roughly east of the great continental divide, at a grid resolution of $36 \mathrm{~km} \times 36 \mathrm{~km}$. Vertically, the model domain extends up to $5 \mathrm{~km}$, which is divided into 16 layers. The UCD/CIT model was run for California from 20 July to 2 August 2005 and for the eastern US from 20 August to 2 September 2006.

\subsection{Emissions}

Anthropogenic VOC and primary particulate emissions for California are based on the California Regional $\mathrm{PM}_{10} / \mathrm{PM}_{2.5}$ Air Quality Study (CRPAQS) inventory of 2000 but scaled to 2005 by adjusting emissions in 2000 by fuel consumption activity (CARB, 2011); emissions for area sources, point sources, and off-road sources are not changed from their year 2000 levels. FINN (Fire Inventory for National Center for Atmospheric Research) (Wiedinmyer et al., 2011) and MEGAN (Model of Emissions of Gases and Aerosols from Nature) (Guenther et al., 2006) are used to calculate wildfire and biogenic emissions, respectively, in California. Anthropogenic and wildfire VOC and primary particulate emissions for the eastern US are based on the 2005 National Emissions Inventory (NEI) and biogenic emissions are estimated using BEIS (Biogenic Emissions Inventory System) version 3. More details pertaining to the emissions can be found in Jathar et al. (2015)

The chemical mechanism SAPRC-11 is used to represent the gas-phase chemistry, from which the following model species are considered to form SOA: ALK5 (long alkanes), BENZENE (benzene), ARO1 and ARO2 (other aromatics), ISOPRENE (isoprene), TRP1 (monoterpenes) and SQT (sesquiterpenes). Except for alkanes, emissions of these model species are directly used by the SOM.

The carbon number and structure of an alkane influences its SOA mass yield; for the same structure the SOA potential increases with carbon number (Lim and Ziemann, 2009; Presto et al., 2010), while for the same carbon number cyclic alkanes form the most SOA followed by linear and then branched alkanes (Lim and Ziemann, 2009; Tkacik et al., 2012). However, in 3-D models that employ SAPRC11, a single model VOC species, ALK5, is used to describe the SOA formation from alkanes roughly larger than a carbon number of 6 . In order to more accurately represent the SOA formation from alkanes and specifically the carbon chain-length dependence, ALK5 is split by carbon number into seven separate species that represent alkane emissions ranging from 6 to 13 carbon atoms (i.e., ALK_Cxx, where $\mathrm{xx}=06-13)$. Specific details about how the alkane emissions are built from CRPAQS and NEI and incorporated into SAPRC-11 can be found in the Appendix. It should be noted that the split ALK_Cxx emissions generally decrease with increasing carbon number.

\subsection{Meteorology and initial/boundary conditions}

The Weather Research and Forecasting (WRF) v3.4 model (www.wrf-model.org) is used to generate hourly meteorological fields for both episodes. The National Center for Environmental Protection's (NCEP) North American Mesoscale (NAM) analysis data are used to set the initial and boundary conditions for WRF. Results from the global model MOZART-4/NCEP (Model for OZone and Related chemical Tracers 4) are used to set gas- and particle-phase initial and hourly-varying boundary conditions; more details can be found in Emmons et al. (2010).

\subsection{Base SOA model}

The "Base" SOA model is equivalent to that used in the Community Multiscale Air Quality (CMAQ) model version 4.7 (Carlton et al., 2010). This Base model is representative of current-generation SOA models. Here, the SOA precursors in SAPRC-11 oxidize in the gas phase to form fixed semi-volatile or non-volatile products that partition into the particle phase (Odum et al., 1996). SOA formation from aromatics is dependent on the abundance of $\mathrm{NO}_{x}$, forming different product species upon reaction depending on the $\mathrm{NO}_{x}$ condition. Aromatic peroxy radicals $\left(\mathrm{RO}_{2}\right)$ react with $\mathrm{HO}_{2}$ under low $\mathrm{NO}_{x}$ conditions to form non-volatile SOA while they reacted with $\mathrm{NO}$ under high $\mathrm{NO}_{x}$ conditions to form semi-volatile SOA. In addition, the Base model treats the acid enhancement of isoprene SOA (Surratt et al., 2007) and irreversible particle-phase oligomerization (Kalberer et al., 2004), which converts semi-volatile condensed-phase species into non-volatile species. We do not consider SOA formation from IVOCs or via aqueous-phase processing. SOA is assumed to absorptively partition into all OA, including POA. The SOA model species are allowed to dynamically partition to the particle phase as per Kleeman and Cass (2001) (and corrected according to Aw and Kleeman, 2003):

$$
\frac{\partial C_{m}^{n}}{\partial t}=4 \pi D_{\mathrm{g}, m} \frac{R^{n} N^{n}}{4 \beta^{n}+1}\left(C_{m}^{\mathrm{gas}}-\frac{C_{m}^{n}}{\mathrm{Kp}_{m} C_{\mathrm{OA}}}\right),
$$

where $C_{m}^{n}$ is the particle concentration (in $\mu \mathrm{g} \mathrm{m}^{-3}$ ) of the SOA model species $m$ and for particle size bin $n, D_{\mathrm{g}, m}$ is the gas-phase diffusion coefficient (in $\mathrm{m}^{2} \mathrm{~s}^{-1}$ ), $R^{n}$ is the particle radius (in $\mathrm{m}$ ), $N^{n}$ is the particle number concentration (in $\left.\mathrm{m}^{-3}\right), \beta_{m}^{n}$ corrects for non-continuum effects $\left(\beta_{m}^{n}=\right.$ 
$\left.\frac{4 D_{\mathrm{g}, m}}{\alpha_{m} \bar{c}_{m} R^{n}}\right), \bar{c}$ is the mean molecular speed of the gas molecules in $\left(\mathrm{m} \mathrm{s}^{-1}\right), \alpha_{m}$ is the accommodation coefficient, $C_{m}^{\text {gas }}$ is the gas concentration (in $\mu \mathrm{g} \mathrm{m}^{-3}$ ) of the SOA model species, $\mathrm{Kp}_{m}$ is the gas/particle partitioning coefficient (in $\mathrm{m}^{3} \mu \mathrm{g}^{-1}$ ) and $C_{\mathrm{OA}}$ is the total OA concentration (in $\mu \mathrm{g} \mathrm{m}^{-3}$ ). Here, we use an accommodation coefficient of 0.1 , which corresponds to an equilibration timescale of less than $\sim 10$ min (McVay et al., 2014). Changes in $K_{\mathrm{p}}$ with temperature are modeled using the Clausius-Clapeyron equation:

$K_{\mathrm{p}}(T)=K_{\mathrm{p}}\left(T_{\text {ref }}\right) \frac{T}{T_{\text {ref }}}\left[\frac{\Delta H_{\text {vap }}}{R}\left(\frac{1}{T}-\frac{1}{T_{\text {ref }}}\right)\right]$,

where $T_{\text {ref }}$ is the reference temperature (298 K), $\Delta H_{\text {vap }}$ is the enthalpy of vaporization and $R$ is the universal gas constant. We assume a constant $\Delta H_{\mathrm{vap}}$ of $30 \mathrm{~kJ}^{\text {mole }}{ }^{-1}$ for all SOM model species for consistency with the treatment of species in the Base model. This may somewhat underestimate the actual sensitivity to temperature of individual species (Epstein et al., 2010).

\subsection{Statistical oxidation model (SOM)}

\subsubsection{SOM overview}

SOM was used to model the multi-generational, gas-phase oxidation of SOA precursors and their subsequent products along with gas-particle partitioning of all species (Cappa and Wilson, 2012). SOM uses a two-dimensional carbonoxygen grid to track the evolution and properties of gas- and particle-phase organic precursors and products. Each cell in the grid represents a model organic species with a molecular weight defined by the formula $C_{N_{C}} \mathrm{H}_{2 \times N_{\mathrm{C}}+2-N_{\mathrm{O}}} \mathrm{O}_{N_{\mathrm{O}}}$. SOM assumes that the oxygen is bonded to carbon via a single covalent bond and hence the hydrogen number is the same as the species' remaining valence; we assume that the SOM species have a straight chain carbon backbone. A SOM species reflects the average properties (e.g., vapor pressure, reactivity) of all actual species with the same number of carbon $\left(N_{\mathrm{C}}\right)$ and oxygen $\left(N_{\mathrm{O}}\right)$ atoms that are produced from a given precursor class (e.g., aromatics, alkanes). All SOM species are assumed to be reactive towards $\mathrm{OH}$ radicals in the gas phase. These reactions lead to either functionalization or fragmentation, which results in movement through the carbon-oxygen grid. Chamber data are used to fit six precursor-specific adjustable parameters for each precursor class: four parameters that define the molar yields of the four functionalized, oxidized products, one parameter that determines the probability of functionalization or fragmentation, and one parameter that describes the relationship between $N_{\mathrm{C}}, N_{\mathrm{O}}$ and vapor pressure. Each class of precursor species (e.g., aromatics, alkanes) has its own uniquely defined "grid" that describes its gas-phase photochemical oxidation and SOA formation. In the following sections, we describe more details about the SOM and its implementation in the UCD/CIT model.

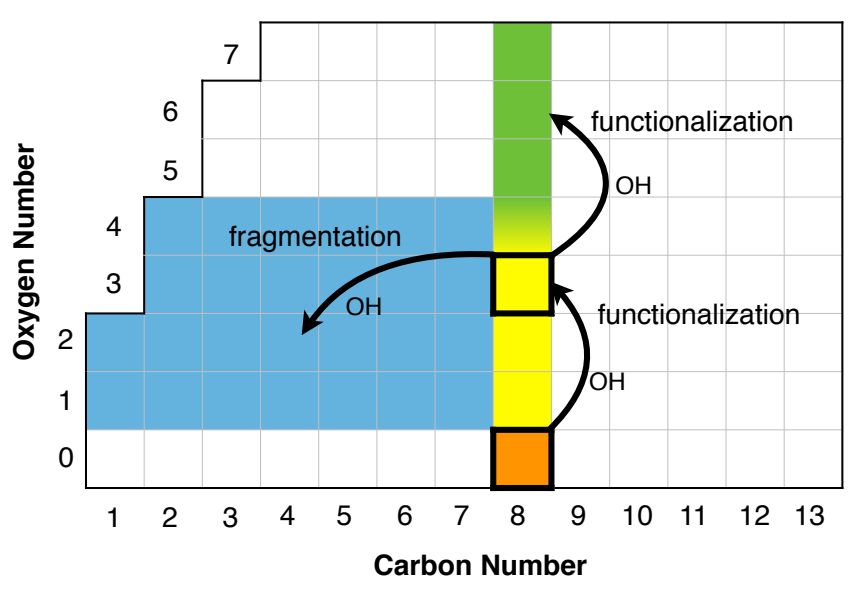

Figure 1. Schematic that demonstrates how the carbon-oxygen grid of the SOM captures the $\mathrm{OH}$-driven multi-generational oxidation of gas-phase organics. Here, a hydrocarbon with eight carbon atoms $\left(\mathrm{C}_{8} \mathrm{H}_{18} \mathrm{O}_{0}\right.$; bordered orange cell) reacts with the $\mathrm{OH}$ radical and functionalizes to form four products with one, two, three and four oxygen atoms (yellow cells). One of the products $\left(\mathrm{C}_{8} \mathrm{H}_{15} \mathrm{O}_{3}\right.$, bordered yellow cell) further functionalizes to form four new products (green cells) or fragments while adding oxygen to form a host of products (blue cells).

\subsubsection{Multi-generational gas-phase oxidation and gas/particle partitioning}

Figure 1 shows a schematic of the carbon-oxygen grid and illustrates the oxidation of a typical SOA precursor and the movement of the product species in the SOM grid. For example, a saturated alkane with eight carbon atoms (ALK_C08 or $\mathrm{C}_{8} \mathrm{H}_{18} \mathrm{O}_{0}$ or $n$-octane; orange cell) reacts with $\mathrm{OH}$ to directly form one of four functionalized products with 1-4 oxygen atoms attached to the carbon backbone (yellow cells). In parallel, an oxygenated species (e.g., $\mathrm{C}_{8} \mathrm{H}_{15} \mathrm{O}_{3}$ ) reacts to form directly functionalized products $\left(\mathrm{C}_{8} \mathrm{H}_{15} \mathrm{O}_{4-7}\right)$ and two fragment species.

The rate coefficients for the reaction of SOA precursors with $\mathrm{OH}$ are the same as those in SAPRC-11 (e.g., at $298 \mathrm{~K}$ ARO1 has a reaction rate coefficient of $6 \times 10^{-12} \mathrm{~cm}^{3}$ molecule $\left.{ }^{-1} \mathrm{~s}^{-1}\right)$. The reaction rate coefficients of nonprecursor SOM species are functions of temperature $(T)$ and carbon and oxygen number (Zhang et al., 2014):

$$
\begin{aligned}
k_{O}\left(N_{\mathrm{C}}, N_{\mathrm{O}}, T\right) & \\
& =A_{1} \\
& +A_{2} \times N_{C}^{A_{3}} \times T^{2} \times \\
& \exp \left(-1 \times \frac{E_{a}}{8.314 \times T}\right) \\
& \times\left[1+\frac{b_{1}}{\sigma \sqrt{2 \pi}}\right. \\
& \left.\exp \left(-\frac{1\left(\ln \left(N_{\mathrm{O}}+0.01\right)-\ln \left(b_{2}\right)\right)^{2}}{2 \sigma^{2}}\right)\right],
\end{aligned}
$$

$\sigma\left(N_{\mathrm{C}} \leq 15\right)=0.0214 \times N_{\mathrm{C}}+0.523 ; \sigma\left(N_{\mathrm{C}}>15\right)$ 
$=-0.115 \times N_{\mathrm{C}}+2.69$,

$b_{1}=-0.258 \times N_{C}+5.89$,

$b_{2}\left(N_{\mathrm{C}} \leq 15\right)=0.0314 \times N_{\mathrm{C}}+0.987 ; b_{2}\left(N_{\mathrm{C}}>15\right)$

$=0.25 \times N_{\mathrm{C}}-2.18$,

where $A_{1}=-15.1, A_{2}=-3.94$, and $A_{3}=-0.797$. It is assumed that the $k_{\mathrm{OH}}$ values for SOM species are the same in all precursor class grids, i.e., are not precursor specific and thus describe the typical reactivities of oxidized hydrocarbon species. The particular dependence of $k_{\mathrm{OH}}$ on $N_{\mathrm{C}}$ and $N_{\mathrm{O}}$ was determined through comparison with results from the chemically explicit GECKO model (Aumont et al., 2005; Camredon et al., 2007).

Each compound has a probability of fragmenting, $P_{\text {frag }}$, or functionalizing, $P_{\text {func }}$, and $P_{\text {func }}+P_{\text {frag }}=1$, and functionalization has a probability of adding $1-4$ oxygen atoms, $p_{i \mathrm{O}}, i=1,4, p_{1 \mathrm{O}}+p_{2 \mathrm{O}}+p_{3 \mathrm{O}}+p_{4 \mathrm{O}}=1$. The molar yield of each directly functionalized product, e.g., $p_{1}$, is therefore $p_{i}=P_{\text {func }} \times p_{i} \mathrm{O}$, so the overall production of directly functionalized products can be written using $n$-octane, as an example,

$\mathrm{C}_{8} \mathrm{H}_{18} \mathrm{O}_{0}+\mathrm{OH} \rightarrow p_{1} \cdot \mathrm{C}_{8} \mathrm{H}_{17} \mathrm{O}_{1}+p_{2} \cdot \mathrm{C}_{8} \mathrm{H}_{16} \mathrm{O}_{2}+$

$p_{3} \cdot \mathrm{C}_{8} \mathrm{H}_{15} \mathrm{O}_{3}+p_{4} \cdot \mathrm{C}_{8} \mathrm{H}_{14} \mathrm{O}_{4}$.

Precursor-specific values of $p_{10}-p_{4 \mathrm{O}}$ and $P_{\text {func }}$ are determined by fitting of the SOM to laboratory measurements.

In the SOM, the probability of fragmentation of a given SOM species, $P_{\text {frag }}$, is dependent on the number of carbon and oxygen atoms and is parameterized as

$P_{\text {frag }}=\left(\frac{N_{\mathrm{O}}}{N_{\mathrm{C}}},\right)^{m_{\text {frag }}}$

where $m_{\text {frag }}$ is a fit parameter. Note that the fragmentation probability of species with zero oxygen atoms is zero in this formulation. In Fig. 1, functionalized (green cells) and fragmented (blue cells) products from the oxidation of the model species $\mathrm{C}_{8} \mathrm{H}_{15} \mathrm{O}_{3}$ are shown. In this case, the probability of fragmentation is $\left(\frac{3}{8}\right)^{m_{\mathrm{frag}}}$. When fragmentation occurs, two molecules are produced for which the total number of carbon atoms, summed over the two molecules, is conserved, but for which the total number of oxygen atoms is increased by two, with one oxygen being added to each fragment. Based on these criteria, all possible fragment species that can be formed from fragmentation of a given SOM species are identified. It is assumed that the formation of every species is equally probable such that the probability of forming a given fragment is $P_{\text {frag }}\left(N_{\mathrm{C}}, N_{\mathrm{O}}\right) / N_{\text {fragments }}\left(N_{\mathrm{C}}, N_{\mathrm{O}}\right)$, where $N_{\text {fragments }}\left(N_{\mathrm{C}}, N_{\mathrm{O}}\right)$ is the $\mathrm{SOM}$ species-specific number of possible fragments (note that this criterion differs from the original SOM parameterization in Cappa and Wilson (2012), where it was assumed that the individual fragments are generated with random probabilities). We should note that the representation of the reaction chemistry in the SOM, in contrast to an explicit gas-phase mechanism like SAPRC, MCM or GECKO, is significantly simplified to capture the average chemistry. Furthermore, each oxidation step in the SOM is an aggregation of numerous individual reaction steps, i.e., intermediate radical species are not explicitly simulated. For example, in reality each oxidation reaction is initiated through hydrogen abstraction to yield peroxy/alkoxy radicals. These radicals can go on to react (with $\mathrm{HO}_{2}, \mathrm{RO}_{2}$ or $\mathrm{NO}$ ) or undergo isomerization to form low-volatility products such as organic nitrates, peroxides and hydroxy carbonyls, or can decompose leading to production of oxygenated fragments. These intermediate steps are not explicitly simulated, only the formation of the resulting stable product species.

The volatility of the model SOM species, and hence its propensity to partition to the particle phase, is defined by its $N_{\mathrm{C}}$ and $N_{\mathrm{O}}$. The volatility is represented by the gas/particle partitioning coefficient $\left(K_{\mathrm{p}}\right)$ (Pankow, 1994) and parameterized as

$K_{\mathrm{p}_{i, j, k}}=\frac{1}{10^{\left(-0.0337 \times \mathrm{MW}_{j, k}+11.56-N_{\mathrm{O}} \times \Delta \mathrm{LVP}_{i}\right)}}$,

where $K_{\mathrm{p}_{i, j, k}}$ is the partitioning coefficient (in $\mathrm{m}^{3} \mu \mathrm{g}^{-1}$ ) for precursor-specific grid $i$, carbon number $j$, and oxygen number $k ; \mathrm{MW}_{j, k}$ is the molecular weight of the hydrocarbon backbone (in $\mathrm{g} \mathrm{mole}^{-1}$, accounting only for carbon and hydrogen atoms) and $\Delta \mathrm{LVP}_{i}$ is the decrease in volatility of the model species per addition of oxygen atom for grid $i$. This last term, $\Delta \mathrm{LVP}_{i}$, reflects the average change in vapor pressure due to the functional group added upon oxidation (e.g., alcohol, ketone) and is determined by fitting the SOM to chamber data. Differences in values of $\Delta \mathrm{LVP}_{i}$ between different SOA precursors reflect differences in chemical reaction pathways between these precursors (Cappa and Wilson, 2012; Cappa et al., 2013). The SOM model species are allowed to dynamically partition to the particle phase as per Eq. (1).

In summary, as a VOC undergoes multi-generational oxidation, the evolution of its oxidation products in the SOM grid is defined by six parameters: (i-iv) $p_{1}-p_{4}$, the yields of the four products that add one, two, three, and four oxygen atoms, respectively, (v) $m_{\text {frag }}$, the parameter that characterizes the fragmentation probability, $P_{\text {frag }}$, and (vi) $\Delta \mathrm{LVP}$, the decrease in vapor pressure (or volatility) of the species per addition of an oxygen atom. Each of these parameters is determined through fitting of chamber experiments and then used in the regional model simulations.

While the SOM framework can be adapted to explicitly model other production and loss processes (e.g., oligomerization (Yatavelli et al., 2012), heterogeneous reactions (Shiraiwa et al., 2013)) in the atmosphere, in this work we consider only the multi-generational gas-phase oxidation of SOA precursors and their subsequent products. As with all existing SOA parameterizations that are used in 3-D models, inherent in the parameterization are the effects of condensed-phase 
(and other unaccounted for) processes. As improved understanding of the kinetics and reaction chemistry of key heterogeneous and condensed-phase processes is developed they will be incorporated into the SOM framework The Base simulations include both acid-catalyzed isoprene SOA formation and irreversible oligomerization, while the SOM simulations include neither process. The gas-phase chemistry of the nonSOA forming VOCs is modeled using the gas-phase chemical mechanism, SAPRC-11. As noted above, only SOA formation from traditional VOC precursors is considered here, so as to be consistent with typical applications of CMAQ. However, the SOM framework is general and can incorporate SOA formation from non-traditional SOA precursors, such as SVOC and IVOC. As these SVOC and IVOC species are likely to resemble long-chain alkanes, they can be directly added to the "long alkanes" SOM grid, described in the next section.

\subsubsection{SOM grids and parameterizations}

We use six SOM grids to represent the formation and evolution of SOA with a separate grid for each class of SOA precursors: long alkanes (ALK_C06-ALK_C13), benzene, high-yield aromatics (ARO1), low-yield aromatics (ARO2), isoprene and mono and sesquiterpenes (TRP1 and SESQ). Table 1 lists the SOM parameters for each precursor class. Note that all SAPRC ALK_Cxx species are simulated together using a common grid. The SOM is parameterized for each grid, or precursor class, using data from experiments conducted in the Caltech environmental ("smog") chamber; the last column in Table 1 lists the references for the data. The parameters determined for $n$-dodecane are applied to $\mathrm{C}_{6}-\mathrm{C}_{13}$ alkanes since it was previously shown that the SOM framework captures the observed carbon chain-length dependence of SOA yields (Lim and Ziemann, 2009) for alkanes with good fidelity when a single set of parameters are used (Cappa and Wilson, 2012). The parameters determined for $\alpha$-pinene were also used for all sesquiterpenes, since these parameters were able to predict similar levels of SOA as those measured for a range of sesquiterpenes (Griffin et al., 1999).

Two sets of six parameters were determined for all six grids by separately fitting experiments that were conducted under low $\mathrm{NO}_{x}$ (high yield) and high $\mathrm{NO}_{x}$ (low yield) conditions; the SOM parameters are listed in Table 1. The $\mathrm{NO}_{x}$ dependence of SOA formation is consequently treated in a binary manner because the SOM in its current configuration does not allow for continuous variation in the dependence of SOA on $\mathrm{NO}_{x}$. More details about the fitting process and the experimental chamber data can be found in Cappa et al. (2013) and Zhang et al. (2014). Briefly, measurements of VOC decay during the chamber experiment were used to estimate $\mathrm{OH}$ concentrations that were then used to represent the oxidation of the SOM model species. Values of the six parameters were determined with the built-in curve fitting tool in IGOR Pro 6.3 (Wavemetrics, Lake Oswego,
OR) by treating the SOM as a user-defined function. The best fit was determined as that which gave the best agreement between simulated and observed SOA concentrations as a function of time and where OA concentrations had been corrected for particle wall losses. The curve fitting tool used the Levenberg-Marquardt algorithm to minimize the Chisquare parameter. While important, the fitting did not consider the influence of organic gas/vapor losses to the chamber walls (Zhang et al., 2014) and hence the fitted parameters represent the minimum potential of the precursor to form $\mathrm{SOA}$; the influence of gas/vapor wall losses on the SOM parameters and consequently on regional SOA concentrations will be explored in a follow-up study. The fitting was undertaken assuming a monodisperse particle size distribution that matched the aerosol surface area in the chamber experiment and an accommodation coefficient of 1. Using an accommodation coefficient of 1 or 0.1 did not dramatically change the fitted parameters since the timescale to achieve gas/particle equilibrium is less than a few minutes for these conditions and much faster than the timescale of SOA formation in these experiments (Zhang et al., 2014; McVay et al., 2014).

It should be noted that the experimental data used here to determine the SOM fit parameters are not the same data as used in developing the parameters in the Base model (Carlton et al., 2010). This difference in data sets can be expected to lead to some differences in the resulting simulated SOA concentrations. The use of an alternative data set here, with typically newer data, is justified by the higher time resolution on the precursor decay, often longer reaction times, and better quantification of chamber particle wall losses.

\subsubsection{Implementation}

The multi-generational gas-phase oxidation reactions of the SOM were directly added to the gas-phase mechanism of SAPRC-11 using the SAPRC mechanism compiler maintained by UC Davis. This allowed us to control the number of the SOM grids and the parameterizations for each SOM grid; the mechanism compiler is publicly available at http://webwolf.engr.ucdavis.edu/data/mechanism compiler/mechanism_generator_v1.html. The compiler accepts a .RXN SAPRC mechanism file (Carter, 2015) as input and generates a Fortran file that solves the right hand side of the differential equation for all gas-phase species including the SOM model species (see Eq. 10 below). Links to the Fortran output files (one for SOM (low yield) and one for SOM (high yield)) used in this work are also provided at the URL mentioned above. The rules described above that define the fate (production and loss) of any given SOM species have been incorporated into the automated mechanism compiler. The formation of each grid species is governed by

$\frac{\mathrm{d}\left[C_{X} O_{Z}\right],}{\mathrm{d} t}=-k_{\mathrm{OH}}^{X, Z}[\mathrm{OH}]\left[C_{X} O_{Z}\right]$, 
Table 1. SAPRC-11 model species, corresponding SOM grids, surrogate molecules, SOM parameters, O : C, and data source.

\begin{tabular}{|c|c|c|c|c|c|c|c|c|c|c|c|}
\hline \multirow{3}{*}{$\begin{array}{l}\text { SAPRC-11 species } \\
\text { ALK_C06-ALK_C13 }\end{array}$} & \multirow{3}{*}{$\begin{array}{l}\text { SOM Grid } \\
\text { long alkanes }\end{array}$} & \multirow{3}{*}{$\begin{array}{l}\text { Surrogate to } \\
\text { determine } \\
\text { SOM fits } \\
n \text {-dodecane }\end{array}$} & \multirow{3}{*}{$\begin{array}{l}\mathrm{NO}_{x} \\
\text { Low } \\
\text { High }\end{array}$} & \multirow{3}{*}{$\begin{array}{r}\Delta \mathrm{LVP} \\
\\
1.54 \\
1.39\end{array}$} & \multicolumn{4}{|c|}{$P_{\text {func }}$} & \multirow{3}{*}{$\begin{array}{l}m_{\text {frag }} \\
0.122 \\
0.098\end{array}$} & \multirow{3}{*}{$\begin{array}{l}\mathrm{O}: \mathrm{C} \quad(\mathrm{end} \\
\text { of experi- } \\
\text { ment) }\end{array}$} & \multirow{3}{*}{$\begin{array}{l}\text { Reference } \\
\text { Loza et al. (2014) }\end{array}$} \\
\hline & & & & & 0.717 & 0.278 & 0.0028 & 0.0022 & & & \\
\hline & & & & & 0.927 & 0.0101 & 0.018 & 0.0445 & & & \\
\hline \multirow[t]{2}{*}{ Benzene } & \multirow[t]{2}{*}{ benzene } & \multirow[t]{2}{*}{ benzene } & low & 2.01 & 0.769 & 0.001 & 0.0505 & 0.18 & 2.01 & 0.71 & \multirow[t]{2}{*}{ Ng et al. (2007) } \\
\hline & & & high & 1.7 & 0.0792 & 0.001 & 0.919 & 0.001 & 0.535 & 0.97 & \\
\hline \multirow[t]{2}{*}{ ARO1 } & high-yield & \multirow[t]{2}{*}{ toluene } & low & 1.84 & 0.561 & 0.001 & 0.001 & 0.438 & 0.01 & 0.61 & \multirow[t]{2}{*}{ Zhang et al. (2014) } \\
\hline & aromatics & & high & 1.24 & 0.0029 & 0.001 & 0.001 & 1.01 & 0.222 & 1.02 & \\
\hline \multirow[t]{2}{*}{$\mathrm{ARO} 2$} & low-yield & \multirow[t]{2}{*}{$m$-xylene } & low & 1.76 & 0.735 & 0.001 & 0.002 & 0.262 & 0.01 & 0.54 & \multirow[t]{2}{*}{ Ng et al. (2007) } \\
\hline & aromatics & & high & 1.68 & 0.936 & 0.001 & 0.0021 & 0.0609 & 0.01 & 0.55 & \\
\hline \multirow[t]{2}{*}{ Isoprene } & \multirow[t]{2}{*}{ isoprene } & \multirow[t]{2}{*}{ isoprene } & low & 2.26 & 0.973 & 0.001 & 0.001 & 0.026 & 0.01 & 0.81 & \multirow[t]{2}{*}{ Chhabra et al. (2011) } \\
\hline & & & high & 1.94 & 0.952 & 0.0011 & 0.0304 & 0.0163 & 0.0632 & 0.9 & \\
\hline \multirow[t]{2}{*}{ TRP1/SESQ } & \multirow[t]{2}{*}{ terpenes } & \multirow[t]{2}{*}{$\alpha$-pinene } & low & 1.87 & 0.001 & 0.869 & 0.0776 & 0.0525 & 0.01 & 0.4 & \multirow{2}{*}{$\begin{array}{l}\text { Chhabra et al. (2011), } \\
\text { Griffin et al. (1999) }\end{array}$} \\
\hline & & & high & 1.62 & 0.068 & 0.633 & 0.275 & 0.0244 & 0.0353 & 0.5 & \\
\hline
\end{tabular}

$$
\begin{aligned}
& +[\mathrm{OH}] \sum_{k=1}^{4} k_{\mathrm{OH}}^{X, Z-k} P_{\mathrm{func}}^{X, Z-k} p_{O, k}\left[C_{X} O_{Z-k}\right] \\
& +[\mathrm{OH}] \sum_{j=1}^{j_{\max }} \sum_{k=0}^{k_{\max }-Z} k_{\mathrm{OH}}^{X+j, Z-1+k} \frac{P_{\mathrm{frag}}^{X, Z-1+k}}{N_{\text {fragments }}^{X, Z}}\left[C_{X} O_{Z-1+k}\right],
\end{aligned}
$$

where $X$ is the number of carbon atoms, $Z$ is the number of oxygen atoms $(\geq 0), j_{\max }$ is the maximum number of carbon atoms in a grid and $k_{\max }$ is the maximum number of oxygen atoms in a grid (specified here as seven). In the equation, we deliberately omit hydrogen from the representation of the SOM model species for clarity and also because the hydrogen number is not explicitly tracked in the SOM but rather determined by the remaining valence. The maximum number of oxygen atoms considered is restricted by physical limitations. For compounds with large $N_{\mathrm{C}}$, the addition of oxygen by a gas-phase reaction is constrained by the low volatility of the SOM species partitioning most of the compound into the condensed phase. For small $N_{\mathrm{C}}$, large values of $N_{\mathrm{O}}$ give large $N_{\mathrm{O}} / N_{\mathrm{C}}$, which dictates extensive fragmentation. Tests using SOM in the box model formulation indicate that $k_{\max }=7$ is a reasonable threshold such that changing $k_{\max }$ by one oxygen does not affect the results. Compounds with $X$ carbon atoms that would theoretically have more than $k_{\max }$ oxygen atoms based on the rules governing the SOM are placed into the grid cell associated with the $C_{X} O_{k_{\max }}$ species.

A separate operator was added to UCD/CIT to calculate dynamic gas/particle partitioning of the SOM model species. The numerical solutions for the gas-phase chemistry and gas/particle partitioning at each time step were performed using operator splitting. In all, 324 gas-phase species and 2592 (i.e., 324 species across eight size bins) particle-phase SOM model species were added to the UCD/CIT model for the simulations reported here.

\subsection{Simulations and computational considerations}

We performed one simulation with the Base SOA model and two simulations with the SOM SOA model, one using parameters determined from fitting high $\mathrm{NO}_{x}$ (low yield) experiments and one using low $\mathrm{NO}_{x}$ (high yield) parameters. The SOM simulations will be referred to as SOM (low yield) or SOM (high yield). All simulations were performed for both domains: SoCAB and the eastern US. The simulations were performed on a computer cluster operated and maintained at the University of California, Davis. Each simulation was performed using Intel Core i5-3570s for a total of 40 core processors and shared memory of $40 \mathrm{~GB}$. The simulations were performed for 19 days with the first 5 days used for spin up. For the SoCAB, each simulated day required approximately $4 \mathrm{~h}$ of elapsed time so a 19-day episode was simulated in less than 4 days. For the eastern US, each simulated day required approximately $9 \mathrm{~h}$ of elapsed time so a 19-day episode was simulated in about 8 days.

\section{Results}

\subsection{SOA concentrations and precursor-resolved composition}

We plot the domain-wide, 14-day averaged SOA concentrations from the SOM (low yield) and SOM (high yield) simulations for SoCAB in Fig. $2 a$ and $b$ and for the eastern US in Fig. $3 \mathrm{a}$ and b. In SoCAB, the predicted SOA concentrations varied between 0.3 and $1 \mu \mathrm{g} \mathrm{m}^{-3}$ for the SOM (low yield) simulation. Higher concentrations of SOA were predicted on the coast northwest of the Los Angeles metropoli$\tan$ area due to the partitioning of near-coast biogenic SOA into the marine POA emitted in the surf zone. In the eastern US, SOA concentrations from the SOM (low yield) simulation were highest in the southeast US $\left(\sim 2 \mu \mathrm{g} \mathrm{m}^{-3}\right)$ and collocated with large emissions of biogenic VOCs. In both do- 

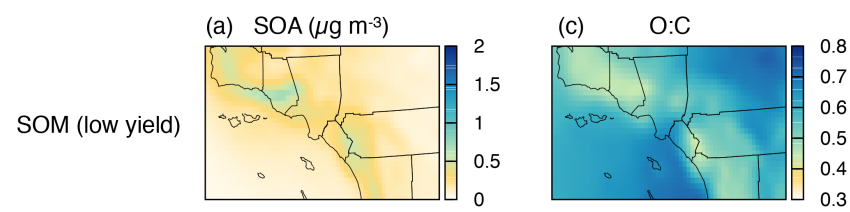

(d)
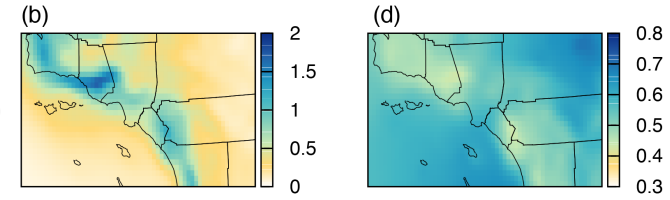

Figure 2. (a, b) 2-week averaged concentrations of SOA (in $\mu \mathrm{g} \mathrm{m}^{-3}$ ) and (c, d) 2-week averaged ratio of $\mathrm{O}: \mathrm{C}$ for southern California. (a, c) are predictions from the SOM (low yield) simulations and (b, d) are predictions from the SOM (high yield) simulations.

mains, the SOA concentrations from the SOM (high yield) simulations were approximately 2-2.5 times higher than the SOA from the SOM (low yield) simulations. Spatially, the distribution of the SOA mass in the SOM (low yield) simulations resembled the distribution in the SOM (high yield) simulations. In Figs. S1 and S2 in the Supplement, the domainwide, 14-day averaged precursor-resolved SOA concentrations from the SOM simulations for SoCAB and the eastern US are shown for comparison. In SoCAB, especially in the Los Angeles metropolitan area, more than $80 \%$ of the $\mathrm{OA}$ is (non-volatile) POA with comparably small contributions from aromatic and monoterpene SOA. Here, the POA was mostly a result of mobile and meat cooking emissions. In the eastern US, while there were POA hotspots around large metropolitan areas (e.g., Houston, TX and Chicago, IL) and along the coast (emissions of marine POA in the surf zone), about half to three-quarters of the OA was SOA. This SOA, especially in the southeast US, comes primarily from monoterpene and sesquiterpene oxidation.

Figure 4 shows the 2-week averaged, precursor-resolved SOA concentrations from the two SOM simulations and the Base simulations at two sites in SoCAB (Los Angeles: urban and Riverside: urban outflow) and at two sites in the eastern US (Atlanta: urban and Smoky Mountains: remote). While there are a few compositional differences, model predictions of total semi-volatile SOA concentrations at all four sites are similar between the SOM (low-yield) and Base simulation; here, semi-volatile SOA excludes acid-catalyzed isoprene SOA and all oligomers formed in the Base model. Similar results could arise from compensating effects of using SOA parameterizations based on newer chamber data than those used in the Base model, the lack of oligomerization reactions and differences in the precursor-specific sensitivity of multi-generational oxidation on SOA mass concentrations. The role of multi-generational oxidation on SOA mass can be explicitly tested only if the Base model is parameterized using the newer chamber data. Since the aim of this paper is to present the implementation of the SOM in a 3-D air qual-

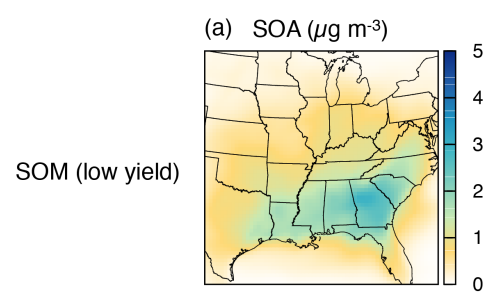

(b)
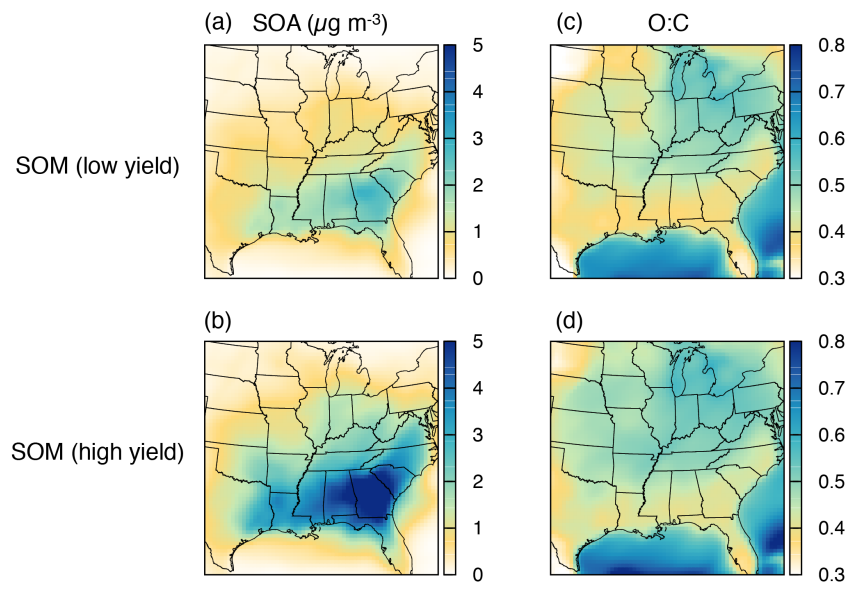

(d)

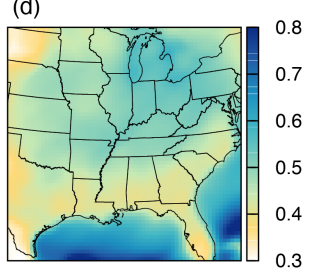

Figure 3. (a, b) 2-week averaged concentrations of SOA (in $\mu \mathrm{g} \mathrm{m}^{-3}$ ) and (c-d) 2-week averaged ratio of $\mathrm{O}: \mathrm{C}$ for the eastern US. (a, c) are predictions from the SOM (low yield) simulations and $(\mathbf{b}, \mathbf{d})$ are predictions from the SOM (high yield) simulations.

ity model, this and other hypotheses regarding the specific role of multi-generational oxidation will be examined in a follow-up paper.

Regardless, the Base model predictions of total semivolatile SOA concentrations at urban Los Angeles, Riverside and Atlanta are similar to those from the SOM (low yield) simulation (that was parameterized using high $\mathrm{NO}_{x}$ chamber data), most likely because urban areas have higher $\mathrm{NO}_{x}$ levels and, correspondingly, lower levels of SOA formation. While the total SOA concentrations were similar, the precursor-resolved composition of SOA (and possibly other important properties of SOA such as volatility) was modestly different between the Base and SOM (low yield) simulations. Alkane SOA concentrations decreased by an order of magnitude at all sites between the Base and SOM simulations, whether high or low yield. This implies that the SOA parameterization used for alkanes in the Base simulation (single model species, ALK5, assumed to have the same SOA potential as $n$-dodecane) might be overpredicting SOA formation from alkanes. This is perhaps not surprising, given that ALK5 emissions are heavily weighted towards smaller alkanes, while the assumed SOA potential corresponds to a longer chain alkane. Compared to the Base simulations, the relative contribution of aromatic, monoterpene and sesquiterpene SOA increased while that of alkane and isoprene SOA decreased in the SOM simulations. Furthermore, the Base simulations suggest that about $30-40 \%$ of the SOA in urban areas and slightly more than $50 \%$ of the SOA in remote areas exist as oligomerized products. Presumably, the SOA concentrations in the SOM simulations would have increased if oligomerization reactions had been included, although this hypothesis remains to be tested explicitly.

At all locations, the SOA composition is different between the SOM (low yield) and SOM (high yield) simulations. The 
Alkane SOA

Aromatic SOA

Isoprene SOA Terpene SOA

Sesquiterpene SOA

Alkane+Aromatic Oligomers |non-volatile

Biogenic Oligomers (a) Los Angeles

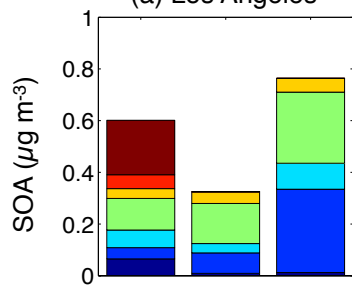

(c) Atlanta

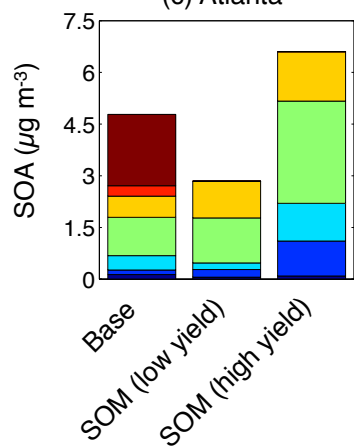

(b) Riverside

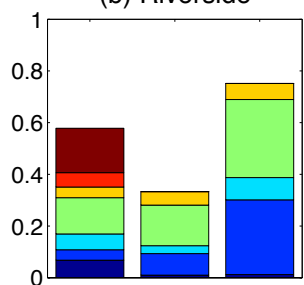

(d) Smoky Mtns

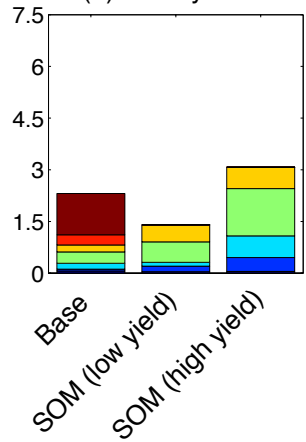

Figure 4. The 2-week averaged SOA concentrations at (a) Los Angeles, (b) Riverside, (c) Atlanta and (d) Smoky Mountains for the Base and SOM simulations resolved by the SOA precursor.

differences in SoCAB are driven by the relatively larger enhancements in aromatic SOA compared to enhancements in SOA from other precursors. For example, aromatic SOA as a fraction of total SOA increased from 24 to $42 \%$ in central Los Angeles between the SOM (low yield) simulation and the SOM (high yield) simulation. Similarly, the differences in SOA composition in the eastern US are driven by the relatively larger enhancements in isoprene SOA compared to enhancements in SOA from other precursors. For example, isoprene SOA as a fraction of total SOA increased from 7 to $17 \%$ in Atlanta between the SOM (low yield) simulation and the SOM (high yield) simulation.

Predictions from the SOM model were compared to measurements made by the aerosol mass spectrometer (AMS) during the Study of Organic Aerosols at Riverside (SOAR) in the summer of 2005 (Docherty et al., 2011, 2008). Over the 2-week simulation, the SOM model underpredicted total OA by $40 \%$ at this location. This suggests that important atmospheric processes and/or emissions sources upwind of Riverside are omitted from the model framework. The SOM model predicted an average SOA concentration of $0.50 \mathrm{\mu g} \mathrm{m}^{-3}$ (average of low yield and high yield), which is $10 \%$ of total OA. The campaign-averaged (30-day) oxygenated OA (OOA) concentration measured by the AMS (sum of the semi-volatile OOA, medium-volatility OOA and composite low-volatility OOA) was $7.1 \mu \mathrm{g} \mathrm{m}^{-3}$ ( $80 \%$ of total OA). Since the model-predicted OA at Riverside is dominated by POA $(\sim 90 \%)$, the $\mathrm{O}: \mathrm{C}$ is controlled by the $\mathrm{O}: \mathrm{C}$ of the emitted POA $(\sim 0.1-0.2)$ and is lower than the campaignaveraged $\mathrm{O}: \mathrm{C}$ of 0.31 inferred from the AMS data. The underprediction (in SOA concentrations and $\mathrm{O}: \mathrm{C}$ ) is typical of predictions in regional (Carlton et al., 2010) and global models (Farina et al., 2010) and arises mostly from an incomplete understanding of the sources and pathways of OA. Numerous factors may contribute to the underprediction of $\mathrm{O}: \mathrm{C}$ at Riverside, including missing emission sources for SOA precursors, semi-volatile and reactive behavior of POA (Robinson et al., 2007), SOA formation from unspeciated emissions (Jathar et al., 2014), aqueous production of SOA in cloud, fog and aerosol water (McNeill, 2015) and multi-generational ageing (Donahue et al., 2012b). The SOM model provides a framework to test these production pathways of OA as our understanding about these processes matures.

\subsection{SOA in carbon-oxygen space}

The number of carbon and oxygen atoms of the SOA model species are explicitly tracked in the SOM and hence the O : C ratio of the SOA can be calculated. The 2-week averaged ratio of oxygen to carbon $(\mathrm{O}: \mathrm{C})$ of SOA from the SOM simulations is shown in Fig. 2c and d for SoCAB and in Fig. 3c and $\mathrm{d}$ for the eastern US. In both domains where the SOA concentrations were higher $\left(>0.5 \mu \mathrm{g} \mathrm{m}^{-3}\right.$ in SoCAB and $>2 \mu \mathrm{g} \mathrm{m}^{-3}$ in the eastern US) and dominated by biogenic VOCs (northwest and south of the Los Angeles metropoli$\tan$ area in SoCAB and the southeast US) the $\mathrm{O}: \mathrm{C}$ of SOA ranged between 0.4 and 0.5 . In these regions, monoterpenes and sesquiterpenes account for a majority of the SOA mass and hence control the average $\mathrm{O}: \mathrm{C}$ of SOA (see Table 1 that lists average $\mathrm{O}: \mathrm{C}$ of SOA predicted by the SOM for the individual surrogate species). The O: C of SOA in the Los Angeles metropolitan area was higher (0.6-0.7) on account of a larger fraction of the SOA coming from aromatic oxidation. In very general terms, aromatic precursors have smaller $N_{\mathrm{C}}$ than mono- and sesquiterpenes, so the average $\mathrm{O}: \mathrm{C}$ of the SOA from aromatics tends to be larger because a greater number of oxygen atoms must be added for the vapor pressures to become sufficiently low for substantial partitioning to the condensed phase (Cappa and Wilson, 2012; Tkacik et al., 2012). The $\mathrm{O}: \mathrm{C}$ of SOA was also higher $(0.5-0.8)$ in regions where the SOA concentrations were lower, probably as a result of sustained multi-generational oxidation tied with longer-range transport and dilution. Broadly, the $\mathrm{O}: \mathrm{C}$ predictions for the SOA are in line with the $\mathrm{O}: \mathrm{C}$ for worldwide ambient oxygenated OA measured using aerosol mass spectrometers (0.4-1.0) (Jimenez et al., 2009). Spatially, there are few differences in the $\mathrm{O}: \mathrm{C}$ between the SOM (low yield) and SOM (high yield) simulations over both domains. In So$\mathrm{CAB}$, the $\mathrm{O}: \mathrm{C}$ decreased by $10 \%$ in the urban areas and 
(a) Los Angeles - SOM (low yield)

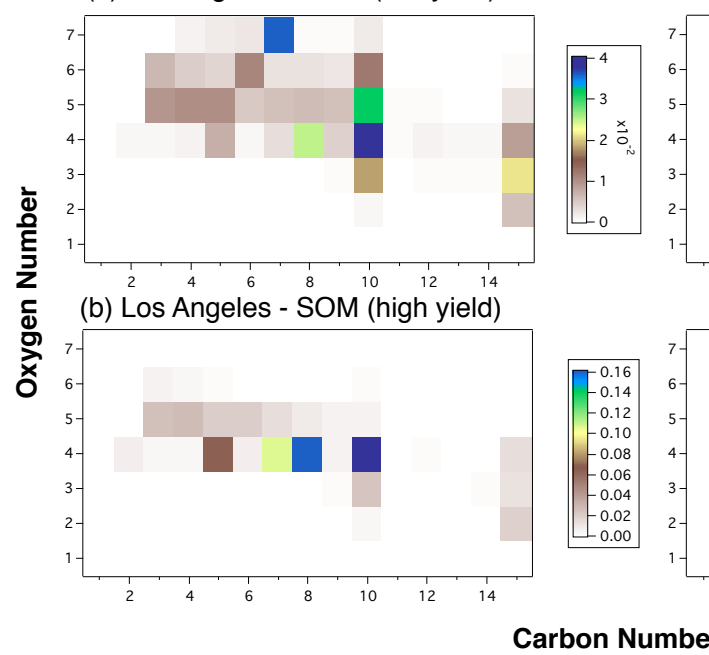

(c) Atlanta - SOM (low yield)

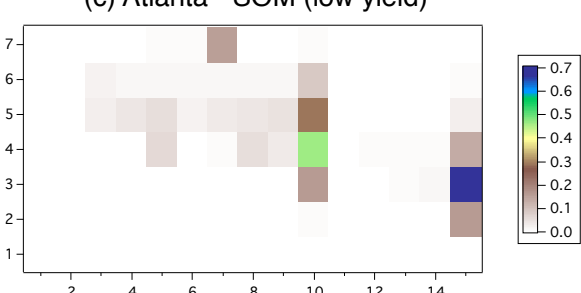

(d) Atlanta - SOM (high yield)

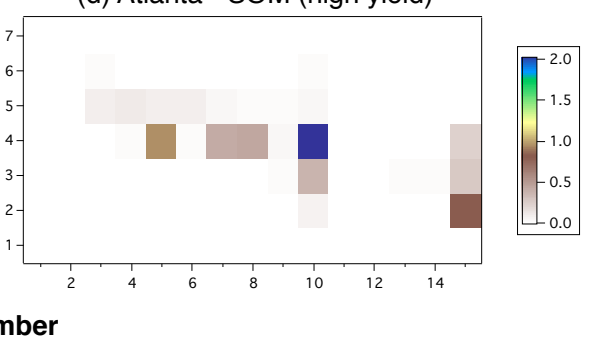

Figure 5. Predicted distribution of the SOA mass (in $\mu \mathrm{g} \mathrm{m}^{-3}$ ) in carbon and oxygen space for Los Angeles (a, b), and Atlanta (c, d) from the SOM (low yield) and SOM (high yield) simulations. Note the different color scales.

increased by $3-5 \%$ in the forested regions between the SOM (low yield) and SOM (high yield) simulations. In the eastern US, the SOM (high yield) simulations predict a slightly higher $\mathrm{O}: \mathrm{C}$ than the SOM (low yield) simulations; approximately $5-10 \%$ higher in the southeast US. The relatively minor changes in $\mathrm{O}: \mathrm{C}$ of SOA, despite modest changes in the SOA composition, suggest that there could be compensating effects, i.e., differences in SOA composition are offset by differences in the $\mathrm{O}: \mathrm{C}$ of the SOA arising from low yield versus high yield pathways.

Recently, high-resolution time-of-flight chemical ionization mass spectrometry (HRToF-CIMS) has been used to resolve the composition of SOA in carbon and oxidation state space (for ambient OA that is dominated by carbon, hydrogen and oxygen, oxidation state $=2 \times \mathrm{O}: \mathrm{C}-\mathrm{H}: \mathrm{C}$ ) (Chhabra et al., 2015; Aljawhary et al., 2013). The SOM enables us to visualize the product distribution of SOA in carbon and oxygen space and allows for a direct comparison with the measurements. While there are no measurements for the episodes simulated in this work, we can anticipate one area where such model-measurement comparisons in carbon-oxygen space could help our understanding of SOA. Figure 5 shows the SOA product distribution (expressed in $\mu \mathrm{g} \mathrm{m}^{-3}$ ) for Los Angeles and Atlanta in carbon-oxygen space. Here, the product distributions in the SOM grid from the SOM (low yield) simulations resemble each other at both locations. In these simulations, the majority of the SOA mass is spread between carbon numbers 3 and 10 and oxygen numbers 3 and 7 and the remainder at carbon number 15 and oxygen numbers 2-4 (associated with sesquiterpenes). While the product distributions from the SOM (high yield) simulations resemble each other too, they occupy a different space in the SOM grid. Here, the SOA mass is narrowly distributed in the oxygen number rows 4 and 5 and carbon number column 10 (associated with monoterpenes). Compared to the SOA mass in the SOM (low yield) simulations, the SOA mass at carbon number 15 (associated with sesquiterpenes) in the SOM (high yield) simulations is relatively lower. It is likely that the differences in product distributions between the SOM low and high yield simulations that represent SOA formation under high and low $\mathrm{NO}_{x}$, respectively, when combined with carbon-oxygen measurements might help us decipher the role of $\mathrm{NO}_{x}$ on SOA formation.

\section{Summary and future work}

The SOM of Cappa and Wilson (2012) is a comprehensive framework to model the atmospheric evolution of OA. In this work, we integrated the SOM with the gas-phase chemical mechanism SAPRC-11 (Carter and Heo, 2013) in the UCD/CIT air quality model and used it to model the multigenerational oxidation and gas/particle partitioning of SOA in the SoCAB and the eastern US. Preliminary results suggest that multi-generational oxidation modestly affects the chemical composition of SOA and hence possibly alters its environmental properties (volatility, deposition, toxicity, etc.). The SOM allows for an explicit calculation of the $\mathrm{O}: \mathrm{C}$ and model predictions of $\mathrm{O}: \mathrm{C}$ of the SOA appear to qualitatively agree with the $\mathrm{O}: \mathrm{Cs}$ measured for ambient OA. With the SOM we are also able to quantify the distribution of the SOA mass in carbon and oxygen space and find that the predicted product distribution is different under the two simulated $\mathrm{NO}_{x}$ levels.

This work has focused on describing the implementation of the SOM in a 3-D air quality model. The SOM offers a more realistic representation of the atmospheric evolution of 
SOA and provides a framework to incorporate many other processes, in addition to multi-generational oxidation, that are central to the OA system. In a follow-up study, we intend to use the SOM to systematically investigate the role of multi-generational oxidation (in conjunction with other important processes such as oligomerization and artifacts associated with vapor wall losses during chamber experiments) on the mass, composition and properties of SOA. 


\section{Appendix A}

An alkane emissions inventory where the emissions are binned by carbon number has been developed. Typically, gas-phase organic emissions (including those for alkanes) are calculated by multiplying the total VOC emissions rate (e.g., $\mathrm{tday}^{-1}$ ) by a normalized VOC profile. The emissions are calculated for each source classification code (SCC) using a SCC-specific VOC profile for all grid cells at every hour. The emissions pre-processor developed at UCD directly uses SAPRC model-speciesspecific VOC profiles (e.g., ALK1 $=0.1$, ALK2 $=0.03$, and ALK3 $=0.01$ ) and hence does not contain carbonnumber specific information to build alkane emissions by carbon number. To do so, we used the California Air Resources Board's speciated database (http://www.arb.ca. gov/ei/speciate/vv10001/profphp/orgspecvv10001_list.php) to rebuild source-resolved, normalized VOC profiles that now included eight new alkane species $\left(\mathrm{C}_{6}-\mathrm{C}_{13}\right)$ to replace the ALK5 species. Only ALK5 is considered since that is the only model species to include alkanes with significant SOA-forming potential. These updated VOC profiles were then used to build gridded emissions for $\mathrm{C}_{6}-\mathrm{C}_{13}$ alkanes; alkanes larger than $\mathrm{C}_{13}$ were lumped into the $\mathrm{C}_{13}$ model species because they accounted for less than $0.5 \%$ of the $\mathrm{C}_{6+}$ alkane emissions. While these emissions could easily have been resolved by alkane structure (linear, branched and cyclic), we did not do so because recent work has suggested that profiles used for emissions inventory building are relatively incomplete in determining emissions of higher carbon-number branched and cyclic alkanes (Gentner et al., 2012). Since the SOA yields for branched and cyclic alkanes are, respectively, lower and higher than those for linear alkanes, we assume that by lumping them together for each carbon number the effective SOA yield is closer to that of a linear alkane. At this point in time, the carbon-number resolved alkane emissions have been developed only for SoCAB. For the eastern US, where a similar speciated database is not available, we use findings from the work of Pye and Pouliot (2012) to determine a linear alkane that could represent SOA formation from ALK5. Pye and Pouliot (2012) determined that national emissions of alkanes higher than a carbon number of six would produced the same amount of SOA as $53 \%$ of $n$-dodecane equivalent emissions. Correcting for differences in SOA mass yields, we assume that the ALK5 behaves like a $\mathrm{C}_{10}$ linear alkane. 


\section{The Supplement related to this article is available online at doi:10.5194/gmd-8-2553-2015-supplement.}

Acknowledgements. The authors thank William Carter for useful discussions regarding SAPRC-11. This work was supported by the California Air Resources Board under contract 12-312. Although this work was funded by the CARB, the statements and conclusions are those of the authors and not necessarily those of the CARB.

Edited by: G. A. Folberth

\section{References}

Aljawhary, D., Lee, A. K. Y., and Abbatt, J. P. D.: High-resolution chemical ionization mass spectrometry (ToF-CIMS): application to study SOA composition and processing, Atmos. Meas. Tech., 6, 3211-3224, doi:10.5194/amt-6-3211-2013, 2013.

Aumont, B., Szopa, S., and Madronich, S.: Modelling the evolution of organic carbon during its gas-phase tropospheric oxidation: development of an explicit model based on a self generating approach, Atmos. Chem. Phys., 5, 2497-2517, doi:10.5194/acp-52497-2005, 2005.

Aumont, B., Valorso, R., Mouchel-Vallon, C., Camredon, M., LeeTaylor, J., and Madronich, S.: Modeling SOA formation from the oxidation of intermediate volatility n-alkanes, Atmos. Chem. Phys., 12, 7577-7589, doi:10.5194/acp-12-7577-2012, 2012.

Aw, J. and Kleeman, M. J.: Evaluating the first-order effect of intraannual temperature variability on urban air pollution, J. Geophys. Res.-Atmos., 108, 4365, doi:10.1029/2002JD002688, 2003.

Baek, J., Hu, Y., Odman, M. T., and Russell, A. G.: Modeling secondary organic aerosol in CMAQ using multigenerational oxidation of semi-volatile organic compounds, J. Geophys. Res.Atmos., 116, D22204, doi:10.1029/2011JD015911, 2011.

Camredon, M., Aumont, B., Lee-Taylor, J., and Madronich, S.: The SOA/VOC/NO $\mathrm{N}_{\mathrm{x}}$ system: an explicit model of secondary organic aerosol formation, Atmos. Chem. Phys., 7, 5599-5610, doi:10.5194/acp-7-5599-2007, 2007.

Cappa, C. D. and Wilson, K. R.: Multi-generation gas-phase oxidation, equilibrium partitioning, and the formation and evolution of secondary organic aerosol, Atmos. Chem. Phys., 12, 9505-9528, doi:10.5194/acp-12-9505-2012, 2012.

Cappa, C. D., Zhang, X., Loza, C. L., Craven, J. S., Yee, L. D., and Seinfeld, J. H.: Application of the Statistical Oxidation Model (SOM) to Secondary Organic Aerosol formation from photooxidation of $\mathrm{C}^{12}$ alkanes, Atmos. Chem. Phys., 13, 1591-1606, doi:10.5194/acp-13-1591-2013, 2013.

CARB: EMFAC (Mobile Source Emission Inventory), in: EMFAC (Mobile Source Emission Inventory), California Air Resources Board, 2011.

Carlton, A. G., Bhave, P. V., Napelenok, S. L., Edney, E. O., Sarwar, G., Pinder, R. W., Pouliot, G. A., and Houyoux, M.: Model representation of secondary organic aerosol in CMAQv4. 7, Environ. Sci. Technol., 44, 8553-8560, 2010.
Carter, W. P. L.: Documentation of the SAPRC Chemical Mechanism Modeling System and Files Part 1. Basic System, California Air Resources Board, 2015.

Carter, W. P. L. and Heo, G.: Development of revised SAPRC aromatics mechanisms, Atmos. Environ., 77, 404-414, 2013.

Chacon-Madrid, H. J. and Donahue, N. M.: Fragmentation vs. functionalization: chemical aging and organic aerosol formation, Atmos. Chem. Phys., 11, 10553-10563, doi:10.5194/acp11-10553-2011, 2011.

Chacon-Madrid, H. J., Presto, A. A., and Donahue, N. M.: Functionalization vs. fragmentation: n-aldehyde oxidation mechanisms and secondary organic aerosol formation, Phys. Chem. Chem. Phys., 12, 13975-13982, doi:10.1039/c0cp00200c, 2010.

Chacon-Madrid, H. J., Henry, K. M., and Donahue, N. M.: Photooxidation of pinonaldehyde at low $\mathrm{NO}_{x}$ : from chemistry to organic aerosol formation, Atmos. Chem. Phys., 13, 3227-3236, doi:10.5194/acp-13-3227-2013, 2013.

Chen, J., Ying, Q., and Kleeman, M. J.: Source apportionment of wintertime secondary organic aerosol during the California regional $\mathrm{PM}_{10} / \mathrm{PM}_{2.5}$ air quality study, Atmos. Environ., 44, 13311340, 2010.

Chhabra, P. S., Ng, N. L., Canagaratna, M. R., Corrigan, A. L., Russell, L. M., Worsnop, D. R., Flagan, R. C., and Seinfeld, J. H.: Elemental composition and oxidation of chamber organic aerosol, Atmos. Chem. Phys., 11, 8827-8845, doi:10.5194/acp-11-88272011, 2011.

Chhabra, P. S., Lambe, A. T., Canagaratna, M. R., Stark, H., Jayne, J. T., Onasch, T. B., Davidovits, P., Kimmel, J. R., and Worsnop, D. R.: Application of high-resolution time-of-flight chemical ionization mass spectrometry measurements to estimate volatility distributions of $\alpha$-pinene and naphthalene oxidation products, Atmos. Meas. Tech., 8, 1-18, doi:10.5194/amt-8-1-2015, 2015.

Docherty, K. S., Stone, E. A., Ulbrich, I. M., DeCarlo, P. F., Snyder, D. C., Schauer, J. J., Peltier, R. E., Weber, R. J., Murphy, S. M., and Seinfeld, J. H.: Apportionment of primary and secondary organic aerosols in Southern California during the 2005 Study of Organic Aerosols in Riverside (SOAR-1), Environ. Sci. Technol., 42, 7655-7662, 2008.

Docherty, K. S., Aiken, A. C., Huffman, J. A., Ulbrich, I. M., DeCarlo, P. F., Sueper, D., Worsnop, D. R., Snyder, D. C., Peltier, R. E., Weber, R. J., Grover, B. D., Eatough, D. J., Williams, B. J., Goldstein, A. H., Ziemann, P. J., and Jimenez, J. L.: The 2005 Study of Organic Aerosols at Riverside (SOAR-1): instrumental intercomparisons and fine particle composition, Atmos. Chem. Phys., 11, 12387-12420, doi:10.5194/acp-11-12387-2011, 2011.

Donahue, N. M., Epstein, S. A., Pandis, S. N., and Robinson, A. L.: A two-dimensional volatility basis set: 1 . organic-aerosol mixing thermodynamics, Atmos. Chem. Phys., 11, 3303-3318, doi:10.5194/acp-11-3303-2011, 2011.

Donahue, N. M., Kroll, J. H., Pandis, S. N., and Robinson, A. L.: A two-dimensional volatility basis set - Part 2: Diagnostics of organic-aerosol evolution, Atmos. Chem. Phys., 12, 615-634, doi:10.5194/acp-12-615-2012, 2012a.

Donahue, N. M., Henry, K. M., Mentel, T. F., Kiendler-Scharr, A., Spindler, C., Bohn, B., Brauers, T., Dorn, H. P., Fuchs, H., Tillmann, R., Wahner, A., Saathoff, H., Naumann, K.-H., Möhler, O., Leisner, T., Müller, L., Reinnig, M.-C., Hoffmann, T., Salo, K., Hallquist, M., Frosch, M., Bilde, M., Tritscher, T., Barmet, P., Praplan, A. P., DeCarlo, P. F., Dommen, J., Prévôt, A. S. H., and 
Baltensperger, U.: Aging of biogenic secondary organic aerosol via gas-phase $\mathrm{OH}$ radical reactions, Proc. Natl. Aca. Sci., 109, 13503-13508, doi:10.1073/pnas.1115186109, 2012b.

Emmons, L. K., Walters, S., Hess, P. G., Lamarque, J. F., Pfister, G. G., Fillmore, D., Granier, C., Guenther, A., Kinnison, D., Laepple, T., Orlando, J., Tie, X., Tyndall, G., Wiedinmyer, C., Baughcum, S. L., and Kloster, S.: Description and evaluation of the Model for Ozone and Related chemical Tracers, version 4 (MOZART-4), Geosci. Model Dev., 3, 43-67, doi:10.5194/gmd3-43-2010, 2010.

Epstein, S. A., Riipinen, I., and Donahue, N. M.: A Semiempirical Correlation between Enthalpy of Vaporization and Saturation Concentration for Organic Aerosol, Environ. Sci. Technol., 44, 743-748, 2010.

Farina, S. C., Adams, P. J., and Pandis, S. N.: Modeling global secondary organic aerosol formation and processing with the volatility basis set: Implications for anthropogenic secondary organic aerosol, J. Geophys. Res., 115, D09202, doi:10.1029/2009JD013046, 2010.

Gentner, D. R., Isaacman, G., Worton, D. R., Chan, A. W., Dallmann, T. R., Davis, L., Liu, S., Day, D. A., Russell, L. M., Wilson, K. R., Weber, R., Guha, A., Harley, R. A., and Goldstein, A. H.: Elucidating secondary organic aerosol from diesel and gasoline vehicles through detailed characterization of organic carbon emissions, Proc. Natl. Aca. Sci., 109, 18318-18323, 2012.

Goldstein, A. H. and Galbally, I. E.: Known and unexplored organic constituents in the earth's atmosphere, Environ. Sci. Technol., 41, 1514-1521, doi:10.1021/es072476p, 2007.

Griffin, R. J., Cocker, D. R., Seinfeld, J. H., and Dabdub, D.: Estimate of global atmospheric organic aerosol from oxidation of biogenic hydrocarbons, Geophys. Res. Lett., 26, 2721-2724, 1999.

Guenther, A., Karl, T., Harley, P., Wiedinmyer, C., Palmer, P. I., and Geron, C.: Estimates of global terrestrial isoprene emissions using MEGAN (Model of Emissions of Gases and Aerosols from Nature), Atmos. Chem. Phys., 6, 3181-3210, doi:10.5194/acp-63181-2006, 2006.

Jathar, S. H., Gordon, T. D., Hennigan, C. J., Pye, H. O. T., Pouliot, G. A., Adams, P. J., Donahue, N. M., and Robinson, A. L.: Unspeciated organic emissions from combustion sources and their influence on the secondary organic aerosol budget in the United States, Proc. Natl. Aca. Sci., 111, 10473-10478, 2014.

Jathar, S. H., Mahmud, A., Barsanti, K. C., Asher, W., Pankow, J. F., and Kleeman, M. J.: Water uptake and its influence on gas/particle partitioning of secondary organic aerosol in the United States, Atmos. Environ., in review, 2015.

Jenkin, M. E., Saunders, S. M., Wagner, V., and Pilling, M. J.: Protocol for the development of the Master Chemical Mechanism, MCM v3 (Part B): tropospheric degradation of aromatic volatile organic compounds, Atmos. Chem. Phys., 3, 181-193, doi:10.5194/acp-3-181-2003, 2003.

Jimenez, J. L., Canagaratna, M. R., Donahue, N. M., Prevot, A. S. H., Zhang, Q., Kroll, J. H., DeCarlo, P. F., Allan, J. D., Coe, H., Ng, N. L., Aiken, A. C., Docherty, K. S., Ulbrich, I. M., Grieshop, A. P., Robinson, A. L., Duplissy, J., Smith, J. D., Wilson, K. R., Lanz, V. A., Hueglin, C., Sun, Y. L., Tian, J., Laaksonen, A., Raatikainen, T., Rautiainen, J., Vaattovaara, P., Ehn, M., Kulmala, M., Tomlinson, J. M., Collins, D. R., Cubison, M. J., E, Dunlea, J., Huffman, J. A., Onasch, T. B., Alfarra, M. R.,
Williams, P. I., Bower, K., Kondo, Y., Schneider, J., Drewnick, F., Borrmann, S., Weimer, S., Demerjian, K., Salcedo, D., Cottrell, L., Griffin, R., Takami, A., Miyoshi, T., Hatakeyama, S., Shimono, A., Sun, J. Y., Zhang, Y. M., Dzepina, K., Kimmel, J. R., Sueper, D., Jayne, J. T., Herndon, S. C., Trimborn, A. M., Williams, L. R., Wood, E. C., Middlebrook, A. M., Kolb, C. E., Baltensperger, U., and Worsnop, D. R.: Evolution of Organic Aerosols in the Atmosphere, Science, 326, 1525-1529, doi:10.1126/science.1180353, 2009.

Kalberer, M., Paulsen, D., Sax, M., Steinbacher, M., Dommen, J., Prevot, A. S. H., Fisseha, R., Weingartner, E., Frankevich, V., and Zenobi, R.: Identification of polymers as major components of atmospheric organic aerosols, Science, 303, 1659-1662, 2004.

Kleeman, M. J. and Cass, G. R.: A 3D Eulerian source-oriented model for an externally mixed aerosol, Environ. Sci. Technol., 35, 4834-4848, 2001.

Kleeman, M. J., Ying, Q., Lu, J., Mysliwiec, M. J., Griffin, R. J., Chen, J., and Clegg, S.: Source apportionment of secondary organic aerosol during a severe photochemical smog episode, Atmos. Environ., 41, 576-591, 2007.

Lane, T. E., Donahue, N. M., and Pandis, S. N.: Simulating secondary organic aerosol formation using the volatility basis-set approach in a chemical transport model, Atmos. Environ., 42, 7439-7451, 2008.

Lim, Y. B. and Ziemann, P. J.: Effects of molecular structure on aerosol yields from $\mathrm{OH}$ radical-initiated reactions of linear, branched, and cyclic alkanes in the presence of NOx, Environ. Sci. Technol., 43, 2328-2334, 2009.

Loza, C. L., Craven, J. S., Yee, L. D., Coggon, M. M., Schwantes, R. H., Shiraiwa, M., Zhang, X., Schilling, K. A., Ng, N. L., Canagaratna, M. R., Ziemann, P. J., Flagan, R. C., and Seinfeld, J. H.: Secondary organic aerosol yields of 12-carbon alkanes, Atmos. Chem. Phys., 14, 1423-1439, doi:10.5194/acp-14-14232014, 2014.

McNeill, V. F.: Aqueous Organic Chemistry in the Atmosphere: Sources and Chemical Processing of Organic Aerosols, Environ. Sci. Technol., 49, 1237-1244, doi:10.1021/es5043707, 2015.

McVay, R. C., Cappa, C. D., and Seinfeld, J. H.: Vapor-Wall Deposition in Chambers: Theoretical Considerations, Environ. Sci. Technol., 48, 10251-10258, 2014.

Nenes, A., Pandis, S. N., and Pilinis, C.: ISORROPIA: A new thermodynamic equilibrium model for multiphase multicomponent inorganic aerosols, Aquatic Geochem., 4, 123-152, 1998.

Ng, N. L., Kroll, J. H., Chan, A. W. H., Chhabra, P. S., Flagan, R. C., and Seinfeld, J. H.: Secondary organic aerosol formation from $m$-xylene, toluene, and benzene, Atmos. Chem. Phys., 7, 3909-3922, doi:10.5194/acp-7-3909-2007, 2007.

Odum, J. R., Hoffmann, T., Bowman, F., Collins, D., Flagan, R. C., and Seinfeld, J. H.: Gas/particle partitioning and secondary organic aerosol yields, Environ. Sci. Technol., 30, 2580-2585, 1996.

Pankow, J. F.: An absorption model of gas/particle partitioning of organic compounds in the atmosphere, Atmos. Environ., 28, 185-188, 1994.

Presto, A. A., Miracolo, M. A., Donahue, N. M., and Robinson, A. L.: Secondary organic aerosol formation from high-NO $\times$ photooxidation of low volatility precursors: n-alkanes, Environ. Sci. Technol., 44, 2029-2034, 2010. 
Pye, H. O. and Pouliot, G. A.: Modeling the role of alkanes, polycyclic aromatic hydrocarbons, and their oligomers in secondary organic aerosol formation, Environ. Sci. Technol., 46, 60416047, 2012.

Pye, H. O. T. and Seinfeld, J. H.: A global perspective on aerosol from low-volatility organic compounds, Atmos. Chem. Phys., 10, 4377-4401, doi:10.5194/acp-10-4377-2010, 2010.

Robinson, A. L., Donahue, N. M., Shrivastava, M. K., Weitkamp, E. A., Sage, A. M., Grieshop, A. P., Lane, T. E., Pierce, J. R., and Pandis, S. N.: Rethinking organic aerosols: Semivolatile emissions and photochemical aging, Science, 315, 1259-1262, 2007.

Saunders, S. M., Jenkin, M. E., Derwent, R. G., and Pilling, M. J.: Protocol for the development of the Master Chemical Mechanism, MCM v3 (Part A): tropospheric degradation of nonaromatic volatile organic compounds, Atmos. Chem. Phys., 3, 161-180, doi:10.5194/acp-3-161-2003, 2003.

Shiraiwa, M., Yee, L. D., Schilling, K. A., Loza, C. L., Craven, J. S., Zuend, A., Ziemann, P. J., and Seinfeld, J. H.: Size distribution dynamics reveal particle-phase chemistry in organic aerosol formation, Proc. Natl. Aca. Sci., 110, 11746-11750, 2013.

Surratt, J. D., Lewandowski, M., Offenberg, J. H., Jaoui, M., Kleindienst, T. E., Edney, E. O., and Seinfeld, J. H.: Effect of acidity on secondary organic aerosol formation from isoprene, Environ. Sci. Technol., 41, 5363-5369, 2007.

Tkacik, D. S., Presto, A. A., Donahue, N. M., and Robinson, A. L.: Secondary organic aerosol formation from intermediate-volatility organic compounds: cyclic, linear, and branched alkanes, Environ. Sci. Technol., 46, 8773-8781, doi:10.1021/es301112c, 2012.

Valorso, R., Aumont, B., Camredon, M., Raventos-Duran, T., Mouchel-Vallon, C., Ng, N. L., Seinfeld, J. H., Lee-Taylor, J., and Madronich, S.: Explicit modelling of SOA formation from $\alpha$-pinene photooxidation: sensitivity to vapour pressure estimation, Atmos. Chem. Phys., 11, 6895-6910, doi:10.5194/acp-116895-2011, 2011.
Wiedinmyer, C., Akagi, S. K., Yokelson, R. J., Emmons, L. K., AlSaadi, J. A., Orlando, J. J., and Soja, A. J.: The Fire INventory from NCAR (FINN): a high resolution global model to estimate the emissions from open burning, Geosci. Model Dev., 4, 625641, doi:10.5194/gmd-4-625-2011, 2011.

Yatavelli, R. L. N., Lopez-Hilfiker, F., Wargo, J. D., Kimmel, J. R., Cubison, M. J., Bertram, T. H., Jimenez, J. L., Gonin, M., Worsnop, D. R., and Thornton, J. A.: A chemical ionization highresolution time-of-flight mass spectrometer coupled to a micro orifice volatilization impactor (MOVI-HRToF-CIMS) for analysis of gas and particle-phase organic species, Aerosol Sci. Technol., 46, 1313-1327, 2012.

Yee, L. D., Craven, J. S., Loza, C. L., Schilling, K. A., Ng, N. L., Canagaratna, M. R., Ziemann, P. J., Flagan, R. C., and Seinfeld, J. H.: Secondary organic aerosol formation from low$\mathrm{NO} \times$ photooxidation of dodecane: Evolution of multigeneration gas-phase chemistry and aerosol composition, J. Phys. Chem. A, 116, 6211-6230, 2012.

Yee, L. D., Kautzman, K. E., Loza, C. L., Schilling, K. A., Coggon, M. M., Chhabra, P. S., Chan, M. N., Chan, A. W. H., Hersey, S P., Crounse, J. D., Wennberg, P. O., Flagan, R. C., and Seinfeld, J. H.: Secondary organic aerosol formation from biomass burning intermediates: phenol and methoxyphenols, Atmos. Chem. Phys., 13, 8019-8043, doi:10.5194/acp-13-8019-2013, 2013.

Zhang, X., Cappa, C. D., Jathar, S. H., McVay, R. C., Ensberg, J. J., Kleeman, M. J., and Seinfeld, J. H.: Influence of vapor wall loss in laboratory chambers on yields of secondary organic aerosol, Proc. Natl. Aca. Sci., 111, 5802-5807, 2014.

Zhao, B., Wang, S., Donahue, N. M., Chuang, W., Hildebrandt Ruiz, L., Ng, N. L., Wang, Y., and Hao, J.: Evaluation of one-dimensional and two-dimensional volatility basis sets in simulating the aging of secondary organic aerosol with smogchamber experiments, Environ. Sci. Technol., 49, 2245-2254, doi:10.1021/es5048914, 2015. 